\title{
Description of Pseudaminobacter gen. nov. with two new species, Pseudaminobacter salicylatoxidans sp. nov. and Pseudaminobacter defluvii sp. nov.
}

\author{
P. Kämpfer, ${ }^{1}$ C. Müller, ${ }^{2}$ M. Mau, ${ }^{3}$ A. Neef, ${ }^{1}$ G. Auling, ${ }^{4}$ H.-J. Busse, ${ }^{5,6}$ \\ A. M. Osborn ${ }^{3}$ and A. Stolz ${ }^{2}$
}

Author for correspondence: Peter Kämpfer. Tel: +4964199 37352. Fax: +496419937359.

e-mail: peter.kaempfer@agrar.uni-giessen.de

1 Institut für Angewandte Mikrobiologie, JustusLiebig-Universität Giessen, D-35390 Giessen, Germany

2 Institut für Mikrobiologie, Universität Stuttgart, D-70569 Stuttgart, Germany

3 Bereich Mikrobiologie, Gesellschaft für Biotechnologische Forschung, D-38124 Braunschweig, Germany

${ }^{4}$ Institut für Mikrobiologie der Universität Hannover, D-30167 Hannover, Germany

5 Institut für Mikrobiologie und Genetik, Universität Wien, A-1030 Vienna, Austria

${ }^{6}$ Institut für Bakteriologie, Mykologie und Hygiene, Veterinärmedizinische Universität, Veterinärplatz 1, A-1210 Vienna, Austria

\begin{abstract}
An aerobic bacterium, strain BN12', which degrades substituted naphthalenesulfonates and substituted salicylates was isolated from a 6aminonaphthalene-2-sulfonate-degrading microbial consortium originating from the River Elbe, Germany. Chemotaxonomic investigations of quinones, polyamines and polar lipids allowed allocation of this strain to the $\alpha$-subclass of the Proteobacteria and revealed similarity to species of the genera Aminobacter, Chelatobacter and Mesorhizobium. This was confirmed by typing with 165 rRNA-targeted oligonucleotide probes and 165 rDNA sequencing and phylogenetic analysis, indicating that BN12 ${ }^{\top}$ clusters most closely with a strain 'Thiobacillus' THI $051^{\top}$ and with the above genera but comprising a separate

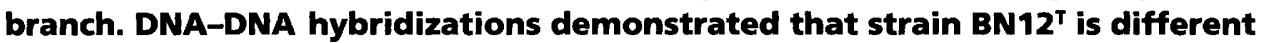
from all species of Aminobacter currently described and recognized. The fatty acid patterns, substrate utilization profile and biochemical characteristics displayed no obvious similarity to the characteristics of Aminobacter and Chelatobacter species. 'Thiobacillus' THI 051', however, revealed phenotypic similarities to BN12'. Furthermore, 16S rRNA sequences of Chelatobacter heintzii showed a high similarity to the 16S rRNA sequences of all currently recognized Aminobacter species. On the basis of these and previously published results, the new genus Pseudaminobacter is proposed, harbouring the two new species Pseudaminobacter salicylatoxidans sp. nov. and Pseudaminobacter defluvii sp. nov. The type strains are BN12 ${ }^{\top}$ (= DSM 6986') and THI $051^{\top}$ ( = IFO 14570'), respectively.
\end{abstract}

Keywords: Pseudaminobacter gen. nov., Pseudaminobacter salicylatoxidans sp. nov., Pseudaminobacter defluvii sp. nov.

\section{INTRODUCTION}

Pure cultures of the genus Pseudomonas and members of the $\alpha$-subclass of Proteobacteria are able to mineralize sulfonated aromatic compounds (Zürrer $e t$ al., 1987; Busse et al., 1989). Plasmid localization and

Abbreviations: DPG, diphosphatidylglycerol; PC, phosphatidylcholine; PDE, phosphatidyldimethylethanolamine; $P E$, phosphatidylethanolamine; PG, phosphatidylglycerol; PL, phospholipid; PME, phosphatidylmonomethylethanolamine.

The GenBank/EMBL accession numbers for the sequences reported in this paper are AF072542, AJ011759, AJ011760, AJ011761 and AJ011762. conjugational transfer of this trait have also been reported (Jahnke et al., 1993). Often, microbial degradation of sulfonated aromatic compounds is accomplished by mixed bacterial cultures (Nörtemann et al., 1986; Nörtemann, 1987; Feigel \& Knackmuss, 1988, 1993; Thurnheer et al., 1988; Jiménez et al., 1991; Contzen et al., 1996; Dangmann et al., 1996). One intensively studied example of the microbial interactions within mixed bacterial cultures is the degradation of amino- and hydroxynaphthalene-2sulfonates. A member of this co-culture, Sphingomonas sp. BN6 (Nörtemann et al., 1986), converts these substrates into the corresponding salicylates basically 
via the same catabolic pathway as described for naphthalene degradation (Nörtemann et al., 1986, 1994; Kuhm et al., 1991, 1993). The salicylates resulting from the degradation of the naphthalenesulfonates are not further metabolized by strain BN6. They are, therefore, excreted in stoichiometric amounts and can be degraded by bacteria harbouring complementary catabolic pathways (Stolz et al., 1992; Stolz \& Knackmuss, 1993a, b).

The mixed culture containing strain BN6 and various (substituted) salicylate(s)-degrading bacteria was maintained for several years by continuous transfers in liquid media with 6-aminonaphthalene-2-sulfonate as the sole source of carbon and energy. After approximately 40 months cultivation, a new strain $\left(\mathrm{BN} 12^{\mathrm{T}}\right.$ ) was observed which was able, on solid media, to degrade 6-aminonaphthalene-2-sulfonate in a pure culture without excreting 5-aminosalicylate (Nörtemann, 1987). Results of partial 16S rRNA sequencing indicated that the organism belongs within the $\alpha$ subclass of the Proteobacteria and, initially, it was presumed that the strain could belong to either the genus Aminobacter or Chelatobacter. Here, we report the results of a comprehensive taxonomic characterization of strain $\mathrm{BN} 12^{\mathrm{T}}$ and the related strain $\mathrm{THI}$ $051^{\mathrm{T}}$ in comparison with representative strains of all Aminobacter species and Chelatobacter heintzii. As a result of this polyphasic approach, we propose the new genus Pseudaminobacter with the two new species Pseudaminobacter salicylatoxidans and Pseudaminobacter defluvii.

\section{METHODS}

Bacterial strains. Strain $\mathrm{BN} 12^{\mathrm{T}}$ was isolated as a 6-aminonaphthalene-2-sulfonate-mineralizing isolate from a microbial consortium originating from the River Elbe, Germany. Strain THI 051 ${ }^{\mathrm{T}}$ was obtained from A. Yokota. Aminobacter aminovorans DSM 7048 , Aminobacter aganoensis DSM 7051 $1^{\mathrm{T}}$, Aminobacter niigataensis DSM $7050^{\mathrm{T}}$ and $C$. heintzii DSM $6450^{\mathrm{T}}$ were obtained from the DSMZ (Deutsche Sammlung von Mikroorganismen und Zellkulturen, Braunschweig, Germany). All strains were maintained on nutrient agar (Oxoid) at $25^{\circ} \mathrm{C}$.

Morphological and physiological characterization. The Gram reactions of $\mathrm{BN} 12^{\mathrm{T}}$ and THI $051^{\mathrm{T}}$ were tested as described by Gerhardt et al. (1994). Cell morphologies of $\mathrm{BN} 12^{\mathrm{T}}$ and THI $051^{\mathrm{T}}$ were observed under a light microscope $(1.250 \times)$ with cells grown for $24 \mathrm{~h}$ at $25^{\circ} \mathrm{C}$ on nutrient agar. Physiological tests were performed with all strains as described previously (Kämpfer et al., 1997).

Cellular fatty acids. Fatty acid methyl esters were extracted from $\mathrm{BN} 12^{\mathrm{T}}$ and $\mathrm{THI} 051^{\mathrm{T}}$ and prepared by the standard protocol of the Microbial Identification system (MIDI; Microbial ID). Extracts were analysed by using a HewlettPackard model HP6890A gas chromatograph equipped with a flame-ionization detector, an automatic sampler, an integrator and a computer, as described previously (Kämpfer \& Kroppenstedt, 1996; Kämpfer et al., 1997).

Polyamines. Polyamines of strains $\mathrm{BN} 12^{\mathrm{T}}$ and THI $051^{\mathrm{T}}$ were extracted and analysed according to Busse et al. (1997).
Polar lipids and quinones. The quinone system of strain $\mathrm{BN} 12^{\mathrm{T}}$ and the polar lipids were determined by TLC as described previously (Kroppenstedt, 1982; Auling et al., 1986, 1993; Tindall, 1990).

Analysis of the $\mathbf{G}+\mathbf{C}$ content. DNAs of BN12 ${ }^{\mathrm{T}}$ and THI $051^{\mathrm{T}}$ were extracted according to Auling et al. (1986) and the $\mathrm{G}+\mathrm{C}$ content was determined by HPLC analyses of the nucleosides (Kaneko et al., 1986). The HPLC apparatus was equipped with a Waters pump (model 510), a model U6K injector, a column oven, a UV detector (Waters 484) and a reverse phase column $(250 \times 4 \mathrm{~mm})$ hypersil $\mathrm{C} 18,5 \mu \mathrm{m}$ particles. The analyses were performed at $30^{\circ} \mathrm{C}$ and nucleosides were measured at $270 \mathrm{~nm}$. The values were calibrated using digested lambda $(49.8 \mathrm{~mol} \% \mathrm{G}+\mathrm{C})$ as a standard.

DNA-DNA hybridizations. Isolation and hybridization of DNA was carried out by using the spectrophotometric method of De Ley et al. (1970) according to Auling et al. (1986).

Whole cell hybridizations. Exponentially growing cells of strain $\mathrm{BN} 12^{\mathrm{T}}$ were cultivated in nutrient bouillon, after harvesting $(10000 \mathrm{~g}, 10 \mathrm{~min})$ suspended in PBS solution (130 mM NaCl, $10 \mathrm{mM}$ sodium phosphate buffer, $\mathrm{pH} \mathrm{7.4)}$ and fixed with $4 \%$ paraformaldehyde as described by Amann et al. (1990). Hybridizations were performed on coated slides as described by Manz et al. (1992) with rhodamine-labelled probes RHI1247 (Ludwig et al., 1998) and ALF1b (Manz et al., 1992). Microscopy was performed with a Zeiss Axioplan 2 using filter set no. 15.

16S rDNA analysis. 16S rDNA sequences were determined as described previously (Kämpfer et al., 1997) using the 'universal primers' 27f, 357f, 530f, 704f, 926f, 1242f, 321r, 685r, 907r, 1069r, 1220r and 1522r (Gerhardt et al., 1994). rDNA sequences were compared against those in the GenBank database using FASTA (Pearson \& Lipman, 1988) to identify related sequences. Sequences were aligned using CLUSTAL W (Thompson et al., 1994). Evolutionary distances were calculated by pairwise comparison of the aligned sequences (Jukes \& Cantor, 1969), excluding all positions where there was a gap in any sequence in the alignment. A neighbour-joining tree (Saitou \& Nei, 1987) was constructed and bootstrap values (1000 replicates) were calculated by the method of Felsenstein (1985). Phylogenies were also constructed by parsimony using the DNAPARS program in PHYLIP (Felsenstein, 1993).

Nucleotide sequence accession numbers. 16S rDNA sequences were deposited in the EMBL/GenBank database with the following accession numbers: BN12 ${ }^{\mathrm{T}}$ (AF072542), $A$. aminovorans (AJ011759), A. aganoensis (AJ011760), $A$. niigataensis (AJ011761) and C. heintzii (AJ011762).

\section{RESULTS AND DISCUSSION}

\section{Morphological and cultural characteristics}

The obligate aerobic heterotrophic strains $\mathrm{BN} 12^{\mathrm{T}}$ and THI $051^{\mathrm{T}}$ grew as circular, entire, slightly convex and smooth, glistening beige colonies with a diameter of $1-3 \mathrm{~mm}$ on nutrient agar (Oxoid). $\mathrm{BN} 12^{\mathrm{T}}$ was able to grow on nutrient agar (Oxoid), R2A agar (Oxoid) and TSB agar (BBL) at temperatures of $20-40^{\circ} \mathrm{C}$. No growth was observed after $7 \mathrm{~d}$ incubation at 10 and $45^{\circ} \mathrm{C}$. The cells were Gram-negative, non-spore- 

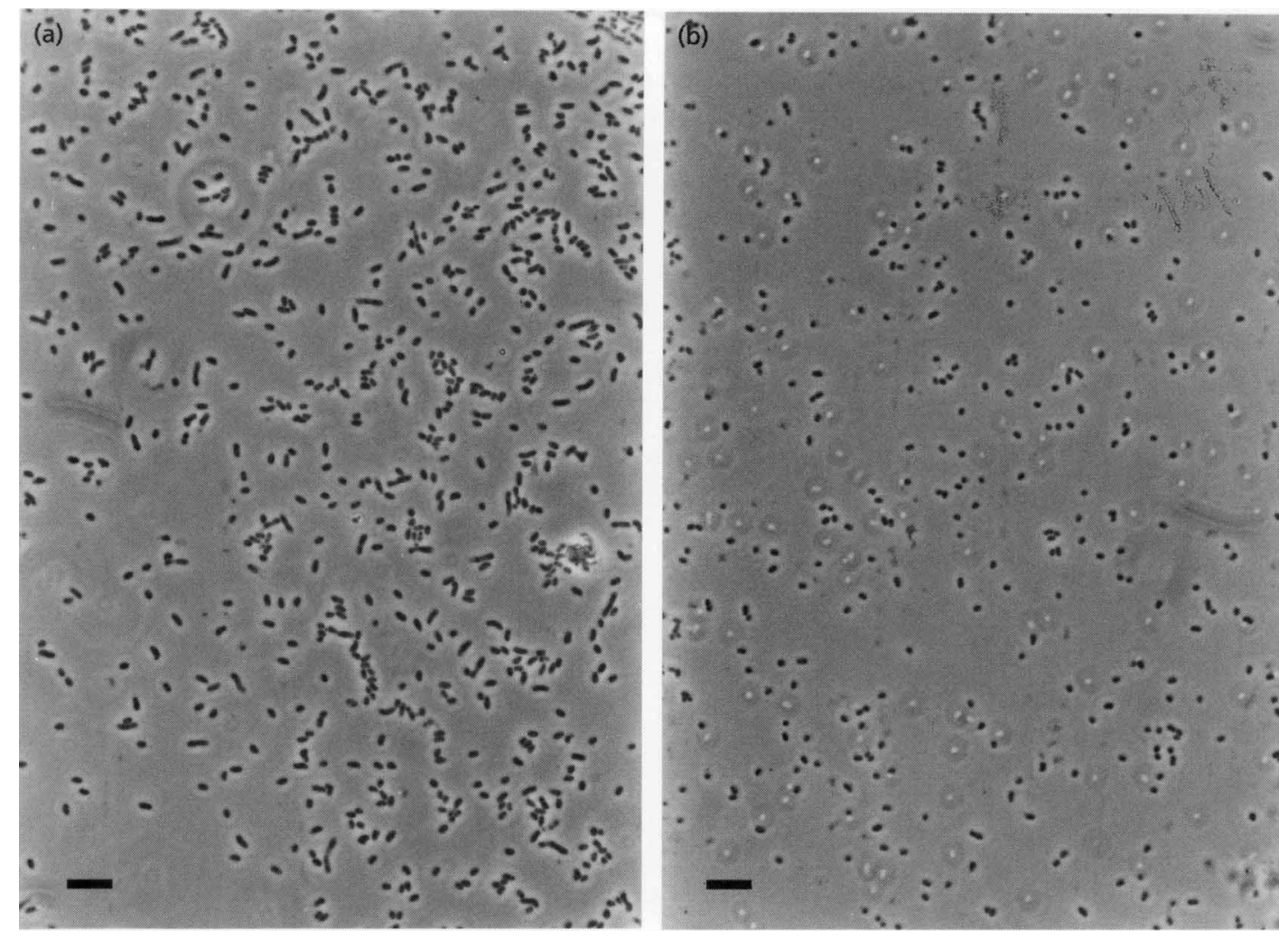

Fig. 1. Phase-contrast micrographs of $B N 12^{\top}$ (a) and $T H I 051^{\top}$ (b). Bar, $5 \mu \mathrm{m}$.

forming, motile, coccoid to rod-shaped with cell dimensions of 1-2 $\mu \mathrm{m}$ (length) and $0.5-0.8 \mu \mathrm{m}$ (width). Fig. 1 shows photomicrographs of $\mathrm{BN} 12^{\mathrm{T}}$ and THI $051^{\mathrm{T}}$, respectively.

\section{Physiological and biochemical characteristics}

$\mathrm{BN} 12^{\mathrm{T}}$ and $\mathrm{THI} 051^{\mathrm{T}}$ were oxidase- and catalasepositive. A large number of organic compounds can be used as sole source of carbon (Table 1). BN12 produced acid aerobically from D-glucose, D-mannitol, dulcitol and melibiose, but only very weak positive results could be observed. THI $051^{\mathrm{T}}$ produced acid only from D-glucose. Table 1 shows that $\mathrm{BN} 12^{\mathrm{T}}$ and THI $051^{\mathrm{T}}$ can be clearly differentiated from one another. Far more differentiating characters can be found for differentiation of the two strains from all Aminobacter species and $C$. heintzii. In addition, several characters differentiated the two strains from Mesorhizobium (Table 3). Where possible, a detailed comparison was made with all previously published data (Auling et al., 1993; Urakami et al., 1992; Jarvis et al., 1997; de Lajudie et al., 1998). Table 1 shows that nearly all test results which could be compared directly with data from previous papers were confirmed. Acid formation from various sugars often resulted in very weak positive results; these test results should be interpreted with care. A numerical analysis of the data were performed by using the simple matching coefficient $\left(S_{\mathrm{SM}}\right)$ and the Jaccard coefficient $\left(S_{\mathrm{J}}\right)$ (Sneath \& Sokal, 1973), and phenograms were generated by using the unweighted pair group with mathematical mean (UPGMA) algorithm. Similar phenograms were generated with the two coefficients. The results of the UPGMA $/ S_{\mathrm{SM}}$ analysis are shown in Fig. 2.

\section{Chemotaxonomy}

$\mathrm{BN} 12^{\mathrm{T}}$ contained a ubiquinone with 10 isoprenoid units in the side chain (ubiquinone Q-10), which is in agreement with the situation in Aminobacter species (Urakami et al., 1992) and C. heintzii (Auling et al., 1993). For THI $051^{\mathrm{T}}$, the presence of ubiquinone Q-10 was reported by Katayama-Fujimura et al. (1984).

The overall polar lipid patterns of $\mathrm{BN} 12^{\mathrm{T}}$ and THI $051^{\mathrm{T}}$ were similar to the patterns determined for the other Aminobacter species and C. heintzii. Nearly the same amounts of the polar lipids phosphatidylcholine (PC), phosphatidylglycerol (PG), phosphatidyldimethylethanolamine (PDE), phosphatidylmonomethylethanolamine (PME), phosphatidylethanolamine (PE) and diphosphatidylglycerol (DPG) were detected in $\mathrm{BN} 12^{\mathrm{T}}$ (Fig. 3) as well as an unidentified phospholipid (PL). THI 051 ${ }^{\mathrm{T}}$ had the same pattern, 
Table 1. Physiological characteristics of the type strains of Pseudaminobacter, Chelatobacter and Aminobacter species

Strains: $1, P$. salicylatoxidans $\mathrm{BN} 12^{\mathrm{T}} ; 2, P$. defluvii $\mathrm{THI} 051^{\mathrm{T}} ; 3$, C. heintzii DSM $6450^{\mathrm{T}} ; 4, A$. aminovorans $\mathrm{DSM} 7048^{\mathrm{T}} ; 5$, A. niigataensis DSM 7050 $; 6$, A. aganoensis DSM 7051 ${ }^{\mathrm{T}}$. +, Positive; -, negative; $(+)$, weak positive; pNP, para-nitrophenyl; pNA, para-nitroanilide. Test results given in the table were read after $72 \mathrm{~h}$ incubation at $30^{\circ} \mathrm{C}$. All strains were negative for: acid production from adonitol, rhamnose, methyl D-glucoside and erythritol; hydrolysis of aesculin, pNP- $\beta$-D-galactopyranoside, pNP$\beta$-D-glucuronide, 2-deoxythymidine- $5^{\prime}$-pNP-phosphate and L-glutamate- $\gamma$-3-carboxy-pNA; and assimilation of $p$-arbutin, $\alpha$-Dmelibiose, salicin, maltitol, putrescine, trans-aconitate, adipate, azelate, fumarate, itaconate, mesaconate, suberate, L-tryptophan, 3-hydroxybenzoate and phenylacetate. All strains were positive for: hydrolysis of L-alanine-pNA and L-proline-pNA; and assimilation of $N$-acetyl-D-glucosamine, 4-aminobutyrate, DL-3-hydroxybutyrate, DL-lactate, oxoglutarate, L-alanine, L-histidine, L-leucine and L-proline.

\begin{tabular}{|c|c|c|c|c|c|c|}
\hline Test & 1 & 2 & 3 & 4 & 5 & 6 \\
\hline \multicolumn{7}{|l|}{ Acid produced from:* } \\
\hline Glucose & $(+)$ & $(+)$ & $(+)$ & $(+) \dagger$ & $(+) \dagger$ & $(+) \dagger$ \\
\hline $\begin{array}{l}\text { Lactose } \\
\text { Sucrose }\end{array}$ & - & - & - & $-t$ & $-\dagger$ & $-\dagger$ \\
\hline $\begin{array}{l}\text { Sucrose } \\
\text { D-Mannitol }\end{array}$ & - & - & $(+)$ & $(+) \dagger$ & $(+) \dagger$ & $(+) \dagger$ \\
\hline $\begin{array}{l}\text { D-Mannitol } \\
\text { Dulcitol }\end{array}$ & $\begin{array}{l}(+) \\
(+)\end{array}$ & - & $(+)$ & $(+) \dagger$ & $(+)^{\dagger}$ & $(+)^{\dagger}$ \\
\hline $\begin{array}{l}\text { Dulcitol } \\
\text { Salicin }\end{array}$ & $\stackrel{(+)}{-}$ & - & $\begin{array}{l}(+) \\
(+)\end{array}$ & $(+)$ & $(+)$ & - \\
\hline Inositol & - & - & $\stackrel{(+)}{-}$ & $\stackrel{(+)}{-}$ & $(+)$ & - \\
\hline Sorbitol & - & - & $(+)$ & - & $(+) \dagger$ & $(+)$ \\
\hline L-Arabinose & - & - & $(+)$ & $(+) \dagger$ & $(+)$ & $\begin{array}{l}(+) \\
-t\end{array}$ \\
\hline Raffinose & - & - & - & $(+)$ & - & - \\
\hline Maltose & - & - & $(+)$ & $(+)$ & $(+) \dagger$ & $(+) \dagger$ \\
\hline D-Xylose & - & - & $(+)$ & $(+) \dagger$ & $(+) \dagger$ & $(+) \dagger$ \\
\hline Trehalose & - & - & $(+)$ & $(+) \dagger$ & $(+) \dagger$ & $-\dagger$ \\
\hline Cellobiose & - & - & $(+)$ & $(+)$ & - & - \\
\hline Melibiose & $(+)$ & - & - & - & - & - \\
\hline D-Arabitol & - & - & $(+)$ & $(+)$ & $(+) \dagger$ & $(+) \dagger$ \\
\hline D-Mannose & - & - & $(+)$ & $(+)$ & $(+)$ & $(+)$ \\
\hline \multicolumn{7}{|l|}{ Hydrolysis of: } \\
\hline pNP- $\alpha$-D-glucopyranoside & - & - & + & + & + & + \\
\hline pNP- $\beta$-D-glucopyranoside & - & - & $(+)$ & $(+)$ & $(+)$ & $(+)$ \\
\hline Bis-pNP-phosphate & + & $(+)$ & + & + & + & + \\
\hline pNP-phenyl-phosphonate & + & + & + & + & $(+)$ & + \\
\hline pNP-phosphorylcholine & - & - & + & + & - & $(+)$ \\
\hline \multicolumn{7}{|l|}{ Assimilation of: } \\
\hline L-Arabinose & - & - & + & $+\dagger$ & $(+) \dagger$ & $+\dagger$ \\
\hline D-Cellobiose & - & - & + & + & + & + \\
\hline D-Fructose & - & - & - & $+\dagger$ & $+\dagger$ & $(+) \dagger$ \\
\hline D-Galactose & - & - & + & $+\dagger$ & $+\dagger$ & $+\dagger$ \\
\hline Gluconate & - & - & -4 & - & - & - \\
\hline D-Glucose & + & + & + & $+\dagger$ & $+\dagger$ & $+\dagger$ \\
\hline D-Mannose & - & - & + & $+\dagger$ & $+\dagger$ & $++^{\dagger}$ \\
\hline D-Maltose & + & - & + & $+\dagger$ & $+\dagger$ & $+\dagger$ \\
\hline L-Rhamnose & - & - & $+\ddagger$ & + & + & - \\
\hline D-Ribose & + & + & + & + & + & + \\
\hline Sucrose & - & - & + & $+\div$ & $+\dagger$ & $+\dagger$ \\
\hline D-Trehalose & + & - & - & - & $+\dagger$ & $+\dagger$ \\
\hline D-Xylose & + & + & + & $+\dagger$ & $+\dagger$ & $+\dagger$ \\
\hline Adonitol & + & - & $-\ddagger$ & - & - & - \\
\hline i-Inositol & - & - & + & $+\dagger$ & $+\dagger$ & $+\dagger$ \\
\hline D-Mannitol & + & - & + & $+\dagger$ & $+\dagger$ & $+t$ \\
\hline D-Sorbitol & + & - & + & $+\dagger$ & $+\dot{\dagger}$ & $+\dagger$ \\
\hline Acetate & + & + & + & $+\dagger$ & $(+) \dagger$ & $(+) \dagger$ \\
\hline Propionate & + & + & $+\ddagger$ & + & - & + \\
\hline cis-Aconitate & + & - & - & - & - & - \\
\hline Citrate & - & - & - & $-\dagger$ & $-\dagger$ & $-\dagger$ \\
\hline Glutarate & + & - & + & + & - & + \\
\hline L-Malate & + & - & - & - & - & + \\
\hline Pyruvate & + & + & - & - & + & + \\
\hline$\beta$-Alanine & + & + & + & - & + & + \\
\hline L-Aspartate & + & - & + & + & + & + \\
\hline L-Ornithine & - & + & + & + & + & + \\
\hline L-Phenylalanine & - & - & $(+) \ddagger$ & - & - & - \\
\hline L-Serine & - & + & + & + & t & + \\
\hline 4-Hydroxybenzoate & + & - & - & - & + & + \\
\hline
\end{tabular}

* Acid formation from carbohydrates in most cases was very weak (even after prolonged incubation). These tests cannot be recommended for differentiation.

$\dagger$ Data are in line with those of Urakami et al. (1992).

$\ddagger$ Data are in line with those of Auling et al. (1992). 
Pseudaminobacter defluvii

Pseudaminobacter salicylatoxidans

Chelatobacter heintzii

Aminobacter aminovorans

Aminobacter niigataensis

Aminobacter aganoensis

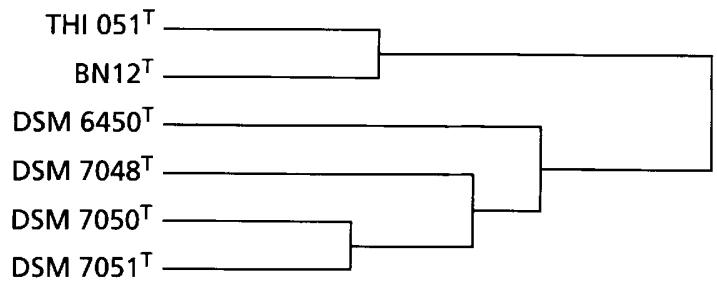

$\begin{array}{ccc}900 & 80 \\ & \text { Similarity }\left(S_{S M}\right)(\%) & \end{array}$

Fig. 2. Phenogram of the type strains of the genera Aminobacter, Chelatobacter and Pseudaminobacter by using the UPGMA analysis and $S_{S M}$.
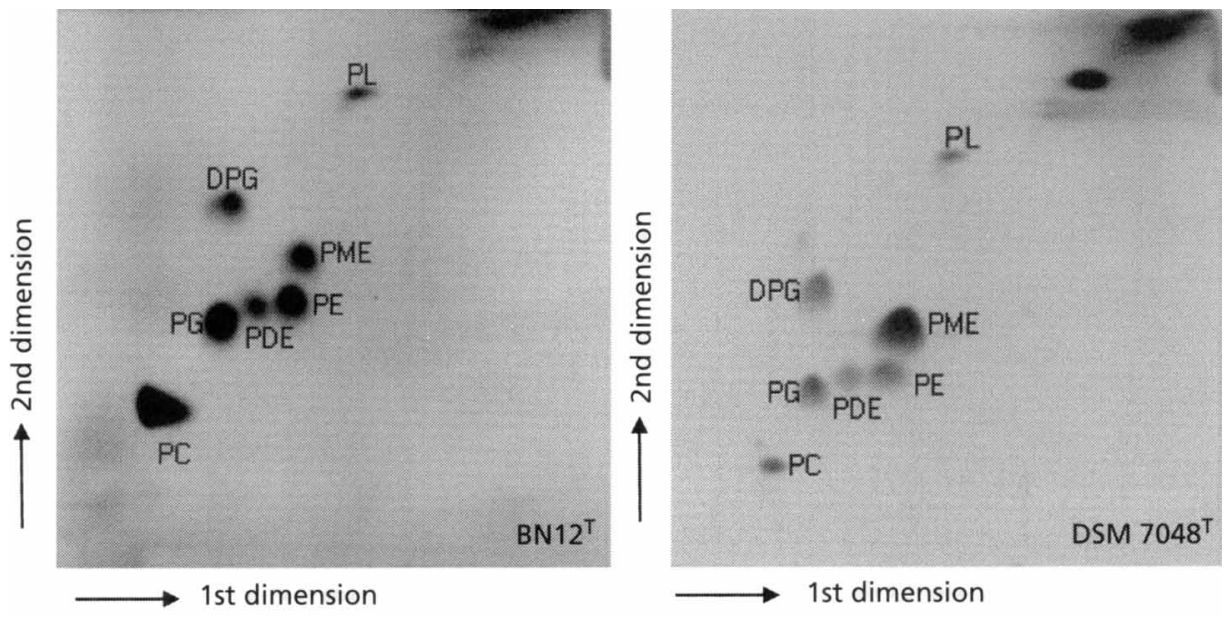

Fig. 3. Polar lipids of $\mathrm{BN} 12^{\top}$ and $A$. aminovorans $\mathrm{DSM} 7048^{\top}$ after separation by two-dimensional TLC. Abbreviations: PC, phosphatidylcholine; $\mathrm{PG}$, phosphatidylglycerol; $\mathrm{PDE}$, phosphatidyldimethylethanolamine; $\mathrm{PME}$, phosphatidylmonomethylethanolamine; PE, phosphatidylethanolamine; DPG, diphosphatidylglycerol; PL, unidentified phospholipid.

but only minor amounts of PDE differentiated the two strains. All three type strains of Aminobacter species and the type strain of $C$. heintzii were very similar with respect to their polar lipid patterns. PME was the sole predominant polar lipid in these four species in contrast to $\mathrm{BN} 12^{\mathrm{T}}$ and THI $051^{\mathrm{T}}$. PC, PG, PDE, PE, DPG and an unidentified phospholipid are present in minor amounts.

Both strains $\mathrm{BN} 12^{\mathrm{T}}$ and THI $051^{\mathrm{T}}$ were also similar in their polyamine patterns. $\mathrm{BN} 12^{\mathrm{T}}$ contained spermidine [32.2 $\mu \mathrm{mol}$ (g dry $\left.\mathrm{wt})^{-1}\right], \quad s y m$-homospermidine $\left[18.6 \mu \mathrm{mol}(\mathrm{g} \text { dry } \mathrm{wt})^{-1}\right]$ and putrescine $[15.6 \mu \mathrm{mol}(\mathrm{g}$ dry $w t^{-1}$ ] as predominant polyamines. Cadaverine $\left[0 \cdot 1 \mu \mathrm{mol}(\mathrm{g} \text { dry } \mathrm{wt})^{-1}\right]$, spermine $[0 \cdot 3 \mu \mathrm{mol}(\mathrm{g}$ dry $\left.\mathrm{wt})^{-1}\right]$ and 1,3-diaminopropane $\left[0.5 \mu \mathrm{mol}(\mathrm{g} \text { dry wt })^{-1}\right]$ were detected in low amounts.

THI $051^{\mathrm{T}}$ also contained spermidine $[16.0 \mu \mathrm{mol}(\mathrm{g}$ dry $\left.\mathrm{wt})^{-1}\right]$, sym-homospermidine [15.5 $\left.\mu \mathrm{mol}(\mathrm{g} \text { dry } \mathrm{wt})^{-1}\right]$ and putrescine [23.9 $\left.\mu \mathrm{mol}(\mathrm{g} \text { dry } \mathrm{wt})^{-1}\right]$ as major polyamines. The organism also contained cadaverine $\left[1.0 \mu \mathrm{mol}(\mathrm{g} \text { dry } \mathrm{wt})^{-1}\right]$, spermine $[1.3 \mu \mathrm{mol}$ (g dry $\left.\mathrm{wt})^{-1}\right]$ and 1,3-diaminopropane $\left[0.5 \mu \mathrm{mol}(\mathrm{g} \text { dry wt })^{-1}\right]$. Both strains were similar with respect to polyamine patterns. BN12 $12^{\mathrm{T}}$ and THI $051^{\mathrm{T}}$ could be clearly distinguished by their polyamine patterns from the three Aminobacter species (Hamana \& Kishimoto, 1996) and from $C$. heintzii (Auling et al., 1993). These species contain polyamine patterns which are characterized by the predominant compound sym-homospermidine, high amounts of putrescine and low amounts of spermidine. Strains BN12 $2^{\mathrm{T}}$, THI $051^{\mathrm{T}}$, all type strains of Aminobacter species and $C$. heintzil contained the fatty acids $16: 0,18: 0,17: 0$ iso, summed feature 4 (16:1 7c and/or 15:0iso 2-OH), summed feature $7(18: 17 c, 18: 19 t$ and/or 18:1 12t) and an unknown fatty acid not identified from the MIDI 
Table 2. Major fatty acid compositions (\%) of type strains of species of the genera Pseudaminobacter, Chelatobacter and Aminobacter

Strain $1, P$. salicylatoxidans $\mathrm{BN} 12^{\mathrm{T}} ; 2, P$. defluvii $\mathrm{THI} 051^{\mathrm{T}} ; 3, C$. heintzii DSM $6450^{\mathrm{T}} ; 4, A$. aminovorans DSM $7048^{\mathrm{T}} ; 5$, A. niigataensis DSM $7050^{\mathrm{T}} ; 6$, A. aganoensis DSM $7051^{\mathrm{T}}$. All strains were grown on Trypticase soy broth agar at $28^{\circ} \mathrm{C}$ for $48 \mathrm{~h}$ prior to fatty acid analysis. For unsaturated fatty acids, the position of the double bond is located by counting from the methyl $(\omega)$ group of the carbon chain; cis is indicated by the suffix $c$. Summed features are groups of two or three fatty acids that cannot be separated by GLC with the MIDI system. Summed feature 4 contained one or more of the following fatty acids: $16: 1 \omega 7 c$ and 15:0iso 2-OH. Summed feature 7 contained one or more of the following isomers: $18: 1 \omega 7 c, 18: 1 \omega 9 t$ and/or $18: 1 \omega 12 t$ (cis and trans isomers are indicated by the suffixes $c$ and $t$, respectively). The unknown fatty acids have no name listed in the Peak library file of the MIDI system and therefore cannot be identified.

\begin{tabular}{|c|c|c|c|c|c|c|}
\hline Compound & 1 & 2 & 3 & 4 & 5 & 6 \\
\hline \multicolumn{7}{|l|}{ Saturated fatty acids: } \\
\hline $16: 0$ & $2 \cdot 3$ & $3 \cdot 7$ & $6 \cdot 3$ & 4.9 & $6 \cdot 0$ & $6 \cdot 2$ \\
\hline $17: 0$ & $9 \cdot 1$ & $3 \cdot 0$ & 0.7 & $0 \cdot 7$ & & \\
\hline $18: 0$ & $2 \cdot 6$ & $1 \cdot 5$ & $2 \cdot 1$ & $1 \cdot 5$ & $2 \cdot 0$ & $2 \cdot 0$ \\
\hline \multicolumn{7}{|l|}{$\begin{array}{l}\text { Unsaturated fatty } \\
\text { acids: }\end{array}$} \\
\hline $15: 1 \omega 8 c$ & & & & & & $1 \cdot 3$ \\
\hline $17: 1 \omega 8 c$ & 3.4 & $3 \cdot 0$ & 0.5 & 0.7 & & \\
\hline $17: 1 \omega 6 c$ & $1 \cdot 2$ & $2 \cdot 0$ & & & & \\
\hline $19: 1 \omega 12 t$ & $1 \cdot 3$ & & & & & \\
\hline $20: 0 \omega 6,9 c$ & 0.6 & & & & & \\
\hline $20: 1 \omega 9 t$ & $0 \cdot 6$ & 1.8 & $0 \cdot 8$ & $0 \cdot 8$ & $0 \cdot 7$ & \\
\hline \multicolumn{7}{|l|}{ Branched fatty acids: } \\
\hline 15:0iso & $1 \cdot 2$ & 0.7 & & & $3 \cdot 1$ & $2 \cdot 9$ \\
\hline 17:0iso & $1 \cdot 5$ & $2 \cdot 0$ & $2 \cdot 6$ & $1 \cdot 0$ & $3 \cdot 0$ & $4 \cdot 8$ \\
\hline \multicolumn{7}{|l|}{ Hydroxy fatty acids: } \\
\hline 12:0 3-O H & & & $0 \cdot 4$ & $0 \cdot 3$ & $0 \cdot 4$ & 0.4 \\
\hline $15: 0$ iso $3-\mathrm{OH}$ & 0.5 & 0.5 & & & & \\
\hline \multicolumn{7}{|l|}{ Summed features: } \\
\hline Summed feature 4 & $0 \cdot 4$ & 0.8 & $0 \cdot 4$ & $0 \cdot 5$ & $1 \cdot 0$ & $1 \cdot 1$ \\
\hline Summed feature 7 & $43 \cdot 4$ & $58 \cdot 5$ & $46 \cdot 2$ & $46 \cdot 4$ & $48 \cdot 6$ & $64 \cdot 8$ \\
\hline \multicolumn{7}{|l|}{ Cyclo propane acids: } \\
\hline 17:0 cyclo & & & & 0.5 & & \\
\hline $19: 0$ cyclo $\omega 8 c$ & $25 \cdot 4$ & $21 \cdot 6$ & $14 \cdot 7$ & $13 \cdot 7$ & $10 \cdot 3$ & 4.7 \\
\hline Unknown 14.966 & & $0 \cdot 7$ & $0 \cdot 6$ & 0.7 & & \\
\hline Unknown 18.081 & $0 \cdot 8$ & & $24 \cdot 5$ & $24 \cdot 8$ & $21 \cdot 0$ & $10 \cdot 9$ \\
\hline Unknown 18.597 & $1 \cdot 2$ & & $0 \cdot 8$ & 0.5 & 1.8 & 0.8 \\
\hline Unknown 18.804 & $4 \cdot 7$ & & $0 \cdot 9$ & 0.4 & $0 \cdot 7$ & \\
\hline
\end{tabular}

database (Table 2). These fatty acids have also been detected in previous studies and are characteristic of all validly described species of the genus Aminobacter (Urakami et al., 1992). The major hydroxy fatty acid in Aminobacter species could be confirmed as 12:0 3-OH. This fatty acid was also detected in $C$. heintzii (Table 2), but not in strains $\mathrm{BN} 12^{\mathrm{T}}$ and THI $051^{\mathrm{T}}$. In contrast, $\mathrm{BN} 12^{\mathrm{T}}$ and THI $051^{\mathrm{T}}$ contained the hydroxylated fatty acid 15:0iso 3-OH, which could not be detected in any Aminobacter and Chelatobacter strains (Table 2). Some additional differences in fatty acid patterns between Aminobacter, Chelatobacter, $\mathrm{BN} 12^{\mathrm{T}}$ and $\mathrm{THI} 051^{\mathrm{T}}$ are shown in Table 2.
The $\mathrm{G}+\mathrm{C}$ content of $\mathrm{BN} 12^{\mathrm{T}}$ was estimated to be 63.9 $\mathrm{mol} \%$. This was very similar to the $\mathrm{G}+\mathrm{C}$ content of THI $051^{\mathrm{T}}$, which was reported to be $62.9 \mathrm{~mol} \%$ (Katayama-Fujimuri et al., 1983).

\section{DNA-DNA similarity}

No close similarities between strain $\mathrm{BN} 12^{\mathrm{T}}$ and the type strains of the species of Aminobacter or Chelatobacter were detected in two series of hybridization experiments with DNA preparations isolated from two batches grown independently. The following similarity values [given as $D$ values $(\%)$ 
Table 3. Main differential characters of the genera Pseudaminobacter, Aminobacter/Chelatobacter and Mesorhizobium

,$+ 90 \%$ or more strains are positive;,$- 90 \%$ or more strains are negative; $+/-$, some strains are positive; ND, not determined or data are not available for all species ( $M$. loti, $M$. huakuii, $M$. mediterraneum, $M$. ciceri, $M$. tianshanense and $M$. plurifarium).

\begin{tabular}{|lccc|}
\hline Characteristic & Pseudaminobacter & $\begin{array}{c}\text { Aminobacter } \\
\text { Chelatobacter }\end{array}$ & Mesorhizobium $\dagger$ \\
\hline Assimilation of: & - & & \\
L-Arabinose & - & + & + \\
D-Cellobiose & - & $+/-$ & $\mathrm{ND}$ \\
D-Fructose & - & - & + \\
Fumarate & - & + & $+\ddagger$ \\
D-Galactose & - & + & ND \\
D-Mannose & - & + & $+\S$ \\
Sucrose & & & $+\S$ \\
Fatty acids: & Absent & Present & Present $\|$ \\
12:0 3-OH & Absent & Absent & Present $\|$ \\
13:0iso 3-OH & Present & Absent & Absent $\|$ \\
15:0iso 3-OH & Spermidine, & sym-Homospermidine, & sym-Homospermidine, \\
Major polyamines & sym-homospermidine, & putrescine & putrescine \\
& putrescine & & \\
\hline
\end{tabular}

* Differentiating characters between Chelatobacter heintzii and Aminobacter species are given in Table 1.

$\dagger$ Data of physiological tests from Jarvis et al. (1997) and de Lajudie et al. (1998).

$\ddagger$ M. tianshanense is negative (Jarvis et al., 1996; de Lajudie et al., 1998).

$\S$ Some strains of $M$. tianshanense are negative (de Lajudie et al., 1998).

\| Data are available only for $M$. loti and $M$. huakuii (from Jarvis et al., 1996).

T Data are only available for M. loti (Hamana et al., 1990).

according to De Ley et al. (1970)] were determined between DNA of strain $\mathrm{BN} 12^{\mathrm{T}}$ and $C$. heintzii ATCC $29600^{\mathrm{T}}\left(=\mathrm{DSM} 6450^{\mathrm{T}}\right) \quad(13.4 \%)$, DNA of $A$. aminovorans NCIB $9039^{\mathrm{T}}$ (= DSM $7048^{\mathrm{T}}$ ) $(18.9 \%$ ), and DNA of $A$. aganoensis DSM $7051^{\mathrm{T}}(22.6 \%)$ and $A$. niigataensis DSM $7050^{\mathrm{T}}(25 \cdot 2 \%)$. The $D$ values obtained represent background levels of the optical method of De Ley et al. (1970) and do not support an allocation of strain $\mathrm{BN} 12^{\mathrm{T}}$ into either of the above genera. Between BN12 $2^{\mathrm{T}}$ and THI $051^{\mathrm{T}}$, a DNA-DNA similarity of $36 \%$ was found, indicating that the two strains do not belong to the same species.

\section{Typing with 16S rRNA-targeted oligonucleotides}

Fixed cells of strains $\mathrm{BN} 12^{\mathrm{T}}$ and THI $051^{\mathrm{T}}$ showed strong hybridization signals with probes RHI 1247 and ALF1b. Binding of these two oligonucleotides supports their taxonomic position as members of the family Rhizobiaceae.

\section{$16 S$ rDNA sequencing}

The nearly complete $16 \mathrm{~S}$ rRNA gene sequences of strains BN12 $2^{\mathrm{T}}$, DSM $7048^{\mathrm{T}}$, DSM $7050^{\mathrm{T}}$, DSM $7051^{\mathrm{T}}$ and DSM $6450^{\mathrm{T}}$ were determined. FASTA analysis of the $\mathrm{BN} 12^{\mathrm{T}}$ sequence showed this strain to be most closely related ( $98 \%$ similarity across $1406 \mathrm{bp}$ ) to THI $051^{\mathrm{T}}$.

The 16S rDNA sequences of $A$. aganoensis and $A$. niigataensis were identical across $1466 \mathrm{bp}$. Similarities of greater than $99.6 \%$ were found between the $16 \mathrm{~S}$ rDNA sequences from all three strains of Aminobacter, that from $C$. heintzii and from that of the methylotrophic proteobacterium strain IMB-1 (accession number AF034798) (Table 4). FASTA analysis of these sequences showed highest similarities to those from another methylotrophic isolate, strain ER2 and to members of the species Mesorhizobium loti and Mesorhizobium ciceri.

An alignment of the 16S rDNA sequences from the strains $\mathrm{BN} 12^{\mathrm{T}}$, THI $051^{\mathrm{T}}$ and ER2, members of the genus Aminobacter, the type strains of the six species of the genus Mesorhizobium (Jarvis et al., 1997), and more distant members of the family Rhizobiaceae was made, and a neighbour-joining tree was constructed following pairwise comparison of these aligned sequences (1376 positions, after exclusion of any position in which a gap was found). The strains $\mathrm{BN} 12^{\mathrm{T}}$ and THI $051^{\mathrm{T}}$ form a distinct group, with overwhelming bootstrap support, which is clearly separate from 
Table 4. Percentage similarities between 165 rDNA sequences from members of the genera Aminobacter, Chelatobacter, Pseudaminobacter, Mesorhizobium and related members of the Rhizobiaceae family and the related isolate ER2

Strain: 1, Aminobacter aganoensis DSM 7051 ${ }^{\mathrm{T}} ; 2$, Aminobacter aminovorans DSM 7048 ${ }^{\mathrm{T}} ; 3$, Chelatobacter heintzii DSM 6450 ${ }^{\mathrm{T}}$; 4, Aminobacter niigataensis DSM 7050 $; 5$, IMB-1; 6, ER2; 7, Pseudaminobacter salicylatoxidans BN12 ${ }^{\mathrm{T}} ; 8$, Pseudaminobacter defluvii THI $051^{\mathrm{T}} ; 9$, Mesorhizobium loti LMG $6125^{\mathrm{T}} ; 10$, Mesorhizobium ciceri UPM-Ca $7^{\mathrm{T}} ; 11$, Mesorhizobium mediterraneum

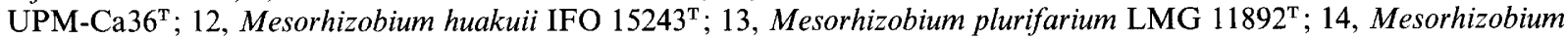
tianshanense A-1BS ${ }^{\mathrm{T}} ; 15$, Phyllobacterium myrsinacearum IAM 13584 ${ }^{\mathrm{T}} ; 16$, Ochrobactrum anthropi IAM 14119 ${ }^{\mathrm{T}} ; 17$, Agrobacterium tumefaciens DSM $30105^{\mathrm{T}}$.

\begin{tabular}{|c|c|c|c|c|c|c|c|c|c|c|c|c|c|c|c|c|c|}
\hline & 1 & 2 & 3 & 4 & 5 & 6 & 7 & 8 & 9 & 10 & 11 & 12 & 13 & 14 & 15 & 16 & 17 \\
\hline 1 & 100 & $99 \cdot 8$ & 99.9 & 100 & 99.6 & $97 \cdot 9$ & 96.8 & 96.7 & $97 \cdot 8$ & $97 \cdot 8$ & $96 \cdot 8$ & $96 \cdot 6$ & $96 \cdot 7$ & 96.0 & $96 \cdot 2$ & 93.8 & 93.6 \\
\hline 2 & & 100 & $99 \cdot 8$ & $99 \cdot 8$ & $99 \cdot 6$ & $97 \cdot 7$ & 96.6 & $96 \cdot 5$ & $98 \cdot 1$ & 98.0 & 97.0 & $96 \cdot 8$ & 96.9 & $96 \cdot 1$ & $96 \cdot 2$ & $93 \cdot 8$ & 93.5 \\
\hline 3 & & & 100 & 99.9 & 99.8 & 97.9 & 96.8 & 96.7 & $98 \cdot 0$ & $97 \cdot 8$ & $96 \cdot 6$ & $96 \cdot 7$ & 96.9 & $96 \cdot 1$ & 96.4 & 93.6 & 93.9 \\
\hline 4 & & & & 100 & $99 \cdot 6$ & 97.9 & 96.8 & 96.7 & $97 \cdot 8$ & $97 \cdot 8$ & $96 \cdot 8$ & 96.6 & 96.7 & $96 \cdot 0$ & $96 \cdot 2$ & $93 \cdot 8$ & $93 \cdot 6$ \\
\hline 5 & & & & & 100 & 97.8 & $96 \cdot 9$ & 96.5 & $97 \cdot 7$ & $97 \cdot 7$ & $96 \cdot 7$ & $96 \cdot 4$ & $96 \cdot 6$ & $95 \cdot 9$ & $96 \cdot 1$ & 93.6 & 93.2 \\
\hline 6 & & & & & & 100 & $95 \cdot 4$ & 94.9 & 95.9 & $95 \cdot 8$ & $95 \cdot 0$ & 95.0 & 94.9 & $94 \cdot 7$ & 94.4 & $92 \cdot 3$ & 91.9 \\
\hline 7 & & & & & & & 100 & 98.0 & $95 \cdot 7$ & 95.9 & 95.9 & $95 \cdot 3$ & $95 \cdot 8$ & $94 \cdot 7$ & $95 \cdot 1$ & 92.8 & $92 \cdot 6$ \\
\hline 8 & & & & & & & & 100 & $96 \cdot 7$ & $96 \cdot 6$ & 96.6 & $96 \cdot 3$ & $96 \cdot 8$ & $95 \cdot 5$ & 96.0 & 93.2 & $92 \cdot 3$ \\
\hline 9 & & & & & & & & & 100 & $99 \cdot 5$ & $98 \cdot 4$ & $98 \cdot 0$ & 98.0 & $97 \cdot 3$ & 96.4 & 94.0 & 93.4 \\
\hline 10 & & & & & & & & & & 100 & $98 \cdot 5$ & $97 \cdot 8$ & 97.9 & $97 \cdot 3$ & $96 \cdot 3$ & 94.0 & $93 \cdot 3$ \\
\hline 11 & & & & & & & & & & & 100 & 98.8 & $98 \cdot 8$ & $97 \cdot 7$ & $96 \cdot 1$ & $94 \cdot 6$ & $93 \cdot 7$ \\
\hline 12 & & & & & & & & & & & & 100 & $99 \cdot 2$ & 97.7 & 96.0 & $94 \cdot 7$ & 93.7 \\
\hline 13 & & & & & & & & & & & & & 100 & $97 \cdot 4$ & 96.4 & 94.8 & $93 \cdot 8$ \\
\hline 14 & & & & & & & & & & & & & & 100 & 94.8 & $94 \cdot 3$ & $94 \cdot 6$ \\
\hline 15 & & & & & & & & & & & & & & & 100 & $94 \cdot 6$ & 92.9 \\
\hline 16 & & & & & & & & & & & & & & & & 100 & $93 \cdot 3$ \\
\hline 17 & & & & & & & & & & & & & & & & & 100 \\
\hline
\end{tabular}

both the genera Aminobacter and Mesorhizobium. Moreover, parsimony analysis of these sequences provided additional confirmation of $\mathrm{BN} 12^{\mathrm{T}}$ and THI $051^{\mathrm{T}}$ forming such a distinct phylogenetic group (data not shown). On the basis of both their phylogenetic and physiological distinction, we propose the description of a new genus Pseudaminobacter gen. nov. containing the species Pseudaminobacter salicylatoxidans sp. nov. and Pseudaminobacter defluvii sp. nov. The study of the generic relationships of members of the genera Aminobacter and Chelatobacter based on 16S rRNA sequence comparisons showed a close relationship between $C$. heintzii and the three Aminobacter species (Fig. 4, Table 4). Results of chemotaxonomic and phenotypic investigations support this (Tables 1 and 2). DNA-DNA similarity studies, however, clearly indicated its species status, but it is obvious that the taxonomic status of the genus Chelatobacter needs revision.

\section{Description of Pseudaminobacter gen. nov.}

Pseudaminobacter (Pseud.ami.no.bac.ter. Gr. adj. pseudos false; M.L. Aminobacter generic name of a bacterium, false aminobacters).

Gram-negative, rod-shaped cells, $1-2 \mu \mathrm{m}$ long by $0 \cdot 5-0.8 \mu \mathrm{m}$ wide, with rounded ends. Cells are motile. Oxidative metabolism. Oxidase-positive. Catalase- poistive. Contains ubiquinone Q-10. The major polyamines are spermidine, sym-homospermidine and putrescine. The overall polar lipid pattern was characterized by nearly the same amounts of the polar lipids PC, PG, PDE, PME, PE and DPG. The cellular fatty acids include a large amount of straight-chain 18:1 acid. The hydroxy acids include the hydroxylated fatty acid 15:0iso 3-OH. Colonies are circular, entire, slightly convex and smooth, glistening and pale beige on nutrient agar at $25^{\circ} \mathrm{C}$. Growth occurs on nutrient agar (Oxoid), Caso agar, R2A agar (Oxoid) and TSB agar (BBL). Several organic compounds can be used as sole source of carbon (Table 1). The $\mathrm{G}+\mathrm{C}$ contents of the DNAs are $62.9-63.9 \mathrm{~mol} \%$ (as determined by HPLC). Phylogenetically, the genus is a member of the $\alpha$-subclass of the Proteobacteria. The type species is Pseudaminobacter salicylatoxidans. At the molecular level, the genus can be recognized by 16S rRNA sequences and fatty acid profiles (Table 3 ).

\section{Description of Pseudaminobacter salicylatoxidans sp. nov.}

Pseudaminobacter salicylatoxidans (sa.li.cy.lat. oxi.dans. N.L. salicyclatoxidans oxidizing salicylate, because the organism oxidizes salicylate in an unusual manner).

Gram-negative, rod-shaped cells are $1-1.5 \mu \mathrm{m}$ long by 


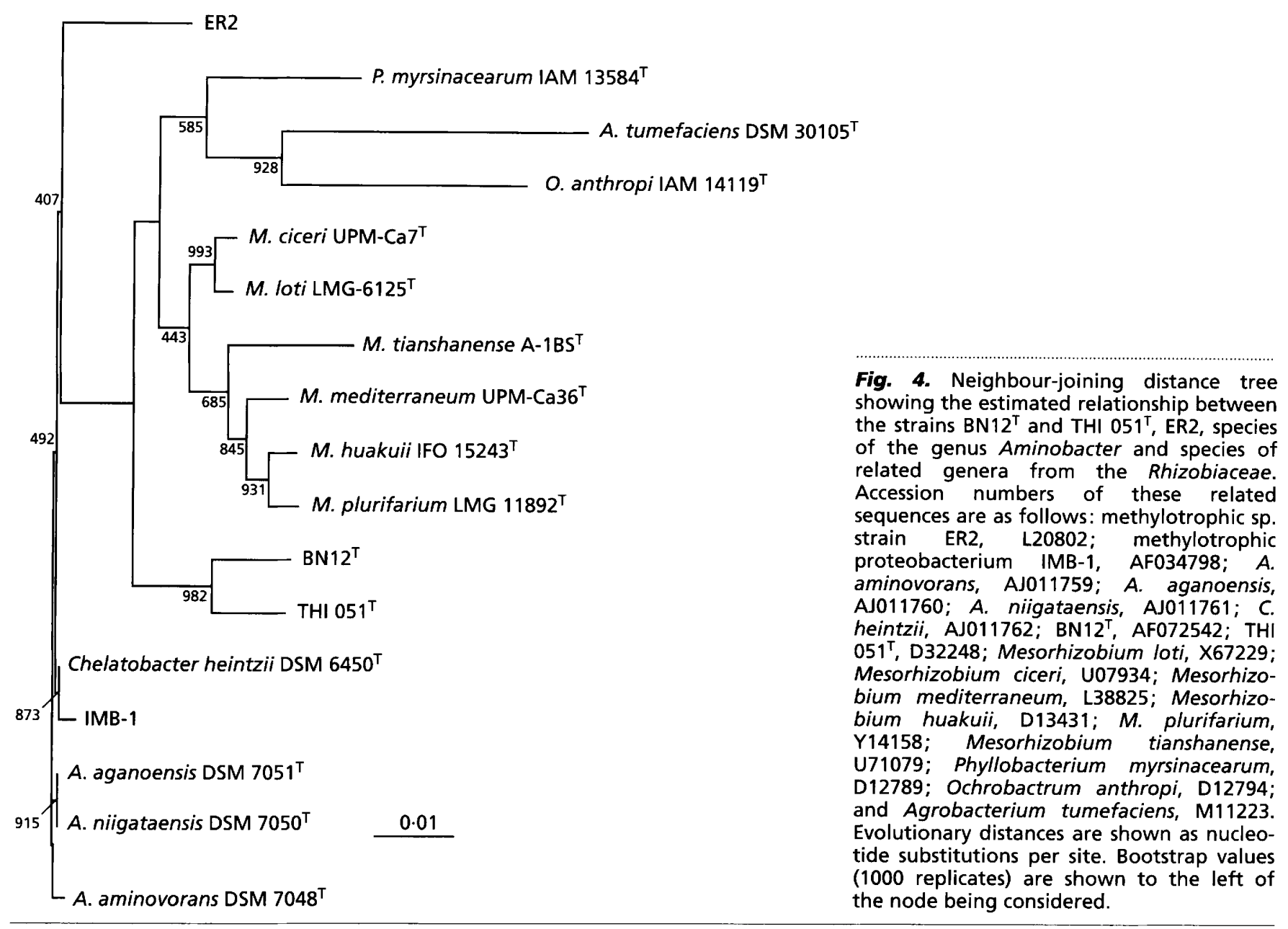

$0 \cdot 5-0.8 \mu \mathrm{m}$ wide, with rounded ends. Cells are motile. Forms circular, entire, slightly convex and smooth, glistening beige colonies with a diameter of $1-3 \mathrm{~mm}$ on nutrient agar (Oxoid). Oxidative metabolism. Oxidasepositive. Able to grow on nutrient agar (Oxoid), R2A agar (Oxoid) and TSB agar (BBL) at temperatures of $20-40{ }^{\circ} \mathrm{C}$. Contains ubiquinone Q-10. The major polyamines are putrescine, spermidine and symhomospermidine. The overall polar lipid pattern was characterized by nearly the same amounts of the polar lipids PC, PG, PDE, PME, PE and DPG. The cellular fatty acids include a large amount of straight-chain 18:1 acid. The hydroxy acids include the hydroxylated fatty acid 15:0iso 3-OH. The utilization of $\mathrm{L}-$ arabinose, D-cellobiose, D-galactose, D-mannose, sucrose, $\mathrm{L}$-ornithine and $\mathrm{L}$-serine (all negative for $\mathrm{BN} 12^{\mathrm{T}}$ ) and adonitol and cis-aconitate (positive for $\mathrm{BN} 12^{\mathrm{T}}$ ) allows differentiation from all Aminobacter species. Hydrolysis of $p$-nitrophenyl $\alpha$-D-glucopyranoside and $p$-nitrophenyl $\beta$-D-glucopyranoside is negative in contrast to all Aminobacter and Chelatobacter strains. The utilization of $\mathrm{L}$-ornithine and $\mathrm{L}$-serine (all negative for $\mathrm{BN} 12^{\mathrm{T}}$ ) and $\mathrm{D}$-maltose, D-trehalose, cis-aconitate, glutarate and $\mathrm{L}$-malate (positive for $\mathrm{BN} 12^{\mathrm{T}}$ ) allows differentiation from THI $051^{\mathrm{T}}$. Other characteristics are shown in Tables 1 and 2. The type strain is strain BN12 ${ }^{\mathrm{T}}$ (= DSM $6986^{\mathrm{T}}$ ). The $\mathrm{G}+\mathrm{C}$ content is 63.9 $\mathrm{mol} \%$.

\section{Description of Pseudaminobacter defluvii sp. nov.}

Pseudaminobacter defluvii (de.flu.vi.i. L. neut. gen. n. fluvius wastewater, because the organism was isolated from activated sludge).

Gram-negative, coccoid to rod-shaped cells are $0 \cdot 8-1 \cdot 2 \mu \mathrm{m}$ long by $0.5-0.8 \mu \mathrm{m}$ wide. Cells are motile. Forms circular, entire, slightly convex and smooth, glistening beige colonies with a diameter of $1-3 \mathrm{~mm}$ on nutrient agar (Oxoid). Oxidative metabolism. Oxidasepositive. Contains ubiquinone Q-10. The major polyamines are putrescine, spermidine and symhomospermidine. The overall polar lipid pattern is characterized by nearly the same amounts of the polar lipids PC, PG, PDE, PME, PE and DPG. The cellular fatty acids include a large amount of straight-chain 18:1 acid. The hydroxy acids include the hydroxylated fatty acid 15:0iso 3-OH. In addition to the characteristics given in the genus description, $P$. defluvii has the following characteristics. Growth occurs between 
10 and $40^{\circ} \mathrm{C}$ and on nutrient agar (Oxoid), Caso agar, R2A agar (Oxoid) and TSB agar (BBL). No growth was visible after incubation at 5 and $45^{\circ} \mathrm{C}$. Several organic compounds can be used as sole source of carbon (Table 1). Other characteristics are shown in Tables 1 and 2. The type strain is strain THI $051^{\mathrm{T}}$ $\left(=\right.$ IFO $\left.14570^{\mathrm{T}}\right)$. The $\mathrm{G}+\mathrm{C}$ content is $62.9 \mathrm{~mol} \%$

\section{ACKNOWLEDGEMENTS}

We gratefully acknowledge the helpful discussions with Edward R. B. Moore. We thank Professor H. G. Trüper for help with the nomenclature, Verena Schmidt for analysis of fatty acids and testing of physiological characters and Inge Reupke for technical assistance during DNA-DNA hybridizations.

\section{REFERENCES}

Amann, R. I., Binder, B. J., Olson, R. J., Chrisholm, S. W., Devereux, R. \& Stahl, D. A. (1990). Combination of 16S rRNAtargeted oligonucleotide probes with flow cytometry for analyzing mixed microbial populations. Appl Environ Microbiol 56, 1919-1925.

Auling, G., Probst, A. \& Kroppenstedt, R. M. (1986). Chemo- and molecular taxonomy of $\mathrm{D}(-)$-tartrate-utilizing pseudomonads. Syst Appl Microbiol 8, 114-120.

Auling, G., Busse, H.-J., Egli, T., El-Banna, T. \& Stackebrandt, E. (1993). Description of the Gram-negative, obligately aerobic, nitrilotriacetate (NTA)-utilizing bacteria as Chelatobacter heintzii gen. nov., sp. nov., and Chelatococcus asaccharovorans gen. nov., sp. nov. Syst Appl Microbiol 16, 104-112.

Busse, H.-J., El-Banna, T. \& Auling, G. (1989). Evaluation of different approaches for identification of xenobiotic-degrading pseudomonads. Appl Environ Microbiol 55, 1578-1583.

Busse, H.-J., Bunka, S., Hensel, A. \& Lubitz, W. (1997). Discrimination of members of the family Pasteurellaceae based on polyamine patterns. Int J Syst Bacteriol 47, 698-708.

Contzen, M., Wittich, R.-M., Knackmuss, H.-J. \& Stolz, A. (1996). Degradation of benzene 1,3-disulfonate by a mixed bacterial culture. FEMS Microbiol Lett 136, 45-50.

Dangmann, E., Stolz, A., Kuhm, A. E., Hammer, A., Feigel, B., Noisommit-Rizzi, N., Rizzi, M., Reuß, M. \& Knackmuss, H.-J. (1996). Degradation of 4-aminobenzenesulfonate by a twospecies bacterial coculture. Biodegradation 7, 223-229.

De Ley, J., Cattoir, H. \& Reynaerts, A. (1970). The quantitative measurement of DNA hybridization from renaturation rates. Eur $J$ Biochem 12, 133-142.

Feigel, B. J. \& Knackmuss, H.-J. (1988). Bacterial catabolism of sulfanilic acid via catechol-4-sulfonic acid. FEMS Microbiol Lett 55, 113-117.

Feigel, B. J. \& Knackmuss, H.-J. (1993). Syntrophic interactions during degradation of 4-aminobenzenesulfonic acid by a two species bacterial culture. Arch Microbiol 159, 124-130.

Felsenstein, J. (1985). Confidence limits on phylogenies: an approach using the bootstrap. Evolution 39, 783-791.

Felsenstein, J. (1993). PHYLIP (Phylogeny Inference Package) version 3.5C. Department of Genetics, University of Washington, Seattle, WA, USA.

Gerhardt, P., Murray, R. G. E., Wood, W. A. \& Krieg, N. R. (1994). Methods for General and Molecular Bacteriology. Washington, DC; American Society for Microbiology.
Hamana, K. \& Kishimoto, N. (1996). Polyamine distribution patterns in $\mathrm{C}_{1}$ compound-utilizing eubacteria and acidophilic eubacteria. $J$ Gen Appl Microbiol 42, 431-437.

Hamana, K., Minamisawa, K. \& Matsuzaki, S. (1990). Polyamines in Rhizobium, Bradyrhizobium, Azorhizobium, and Agrobacterium. FEMS Microbiol Lett 71, 71-76.

Jahnke, M., Lehmann, F., Schoebel, A. \& Auling, G. (1993). Transposition of TOL catabolic genes ( $\operatorname{Tn} 4651)$ into degradative plasmid pSAH of Alcaligenes sp. O-1 ensures simultaneous mineralization of sulpho- and methyl-substituted aromatics. J Gen Microbiol 139, 1959-1966.

Jarvis, B. D. W., Sivakumaran, S., Tighe, T. W. \& Gillis, M. (1996). Identification of Agrobacterium and Rhizobium based on cellular fatty acid composition. Plant Soil 184, 143-158.

Jarvis, B. D. W., van Berkum, P., Chen, W. X., Nour, S. M., Fernandez, M. P., Cleyet-Marel, J. C. \& Gillis, M. (1997). Transfer of Rhizobium loti, Rhizobium huakuii, Rhizobium ciceri, Rhizobium mediterraneum, and Rhizobium tianshanense to Mesorhizobium gen. nov. Int J Syst Bacteriol 47, 895-898.

Jiménez, L., Breen, A., Thomas, N., Federle, T. W. \& Sayler, G. S. (1991). Mineralization of linear alkylbenzene sulfonate by a four-member aerobic bacterial consortium. Appl Environ Microbiol 57, 1566-1569.

Jukes, T. H. \& Cantor, C. R. (1969). Evolution of protein molecules. In Mammalian Protein Metabolism, vol. 3, pp. 21-132. Edited by H. N. Munro. New York: Academic Press.

Kämpfer, P. \& Kroppenstedt, R. M. (1996). Numerical analysis of fatty acid patterns of coryneform bacteria and related taxa. Can $J$ Microbiol 42, 989-1005.

Kämpfer, P., Denner, E. B. M., Meyer, S., Moore, E. R. B. \& Busse, H.-J. (1997). Classification of 'Pseudomonas azotocolligans' Anderson 1955, 132 in the genus Sphingomonas as Sphingomonas trueperi sp. nov. Int J Syst Bacteriol 47, 577-583.

Kaneko, T., Katoh, K., Fujimoto, M., Kumagi, M., Tamaoka, J. \& Katayama-Fujimura, Y. (1986). Determination of the nucleotide composition of a deoxyribonucleic acid by high-performance liquid chromatography of its enzymatic hydrolysates : a review. $J$ Microbiol Methods 4, 229-240.

Katayama-Fujimura, Y., Enokizono, Y., Kaneko, T. \& Kuraishi, H. (1983). Deoxyribonucleic acid homologies among species of the genus Thiobacillus. J Gen Appl Microbiol 29, 287-295.

Katayama-Fujimura, Y., Tsuzaki, N., Hirata, A. \& Kuraishi, H. (1984). Polyhedral inclusion bodies (carboxysomes) in Thiobacillus species with reference to the taxonomy of the genus Thiobacillus. J Gen Appl Microbiol 30, 211-222.

Kroppenstedt, R. M. (1982). Anwendung chromatographischer HP-Verfahren (HPTLC und HPLC) in der Bakterientaxonomie. GIT Lab Med 5, 266-275.

Kuhm, A. E., Stolz, A., Ngai, K.-L. \& Knackmuss, H.-J. (1991). Purification and characterization of a 1,2-dihydroxynaphthalene dioxygenase from a bacterium that degrades naphthalenesulfonic acids. $J$ Bacteriol 173, 3795-3802.

Kuhm, A. E., Knackmuss, H.-J. \& Stolz, A. (1993). Purification and properties of $2^{\prime}$-hydroxybenzalpyruvate aldolase from a bacterium that degrades naphthalenesulfonates. $J$ Biol Chem 268 , 9484-9489.

de Lajudie, P., Willems, A., Nick, G. \& 9 other authors (1998). Characterization of tropical tree rhizobia and description of Mesorhizobium plurifarium sp. nov. Int $J$ Syst Bacteriol 48, 369-382.

Ludwig, W., Amann, R., Martinez-Romero, E., Schönhuber, W., Bauer, S., Neef, A. \& Schleifer, K.-H. (1998). rRNA-based 
identification and detection systems for Rhizobia and other bacteria. Plant Soil 204, 1-19.

Manz, W., Amann, R., Ludwig, W., Wagner, M. \& Schleifer, K.-H. (1992). Phylogenetic oligodeoxynucleotide probes for the major subclasses of Proteobacteria: problems and solutions. Syst Appl Microbiol 15, 593-600.

Nörtemann, B. (1987). Bakterieller Abbau von Amino- und Hydroxynaphthalinsulfonsäuren. $\mathrm{PhD}$ thesis, Universität Stuttgart.

Nörtemann, B., Baumgarten, J., Rast, H. G. \& Knackmuss, H.-J. (1986). Bacterial communities degrading amino- and hydroxynaphthalenesulfonates. Appl Environ Microbiol 52, 1195-1202.

Nörtemann, B., Kuhm, A. E., Knackmuss, H.-J. \& Stolz, A. (1994). Conversion of substituted naphthalenesulfonates by Pseudomonas sp. BN6. Arch Microbiol 161, 320-327.

Pearson, W. R. \& Lipman, D. J. (1988). Improved tools for biological sequence comparison. Proc Natl Acad Sci USA 85, 2444-2448.

Saitou, N. \& Nei, M. (1987). The neighbor-joining method: a new method for reconstructing phylogenetic trees. Mol Biol Evol 4, 406-425.

Sneath, P. H. A. \& Sokal, R. R. (1973). Numerical Taxonomy. San Francisco: W. H. Freeman.

Stolz, A. \& Knackmuss, H.-J. (1993a). Bacterial metabolism of 5aminosalicylic acid: enzymatic conversion to L-malate, pyruvate and ammonia. J Gen Microbiol 139, 1019-1025.
Stolz, A. \& Knackmuss, H.-J. (1993b). Degradation of 2,4dihydroxybenzoate by Pseudomonas sp. BN9. FEMS Microbiol Lett 108, 219-224.

Stolz, A., Nörtemann, B. \& Knackmuss, H.-J. (1992). Bacterial metabolism of 5-aminosalicylic acid: Initial ring-cleavage. Biochem $J$ 282, 675-680.

Thompson, J. D., Higgins, D. G. \& Gibson, T. J. (1994). CLUSTAL W Improving the sensitivity of progressive multiple sequence alignment through sequence weighting, position-specific gap penalties and weight matrix choice. Nucleic Acids Res 22, 4673-4680.

Thurnheer, T., Cook, A. M. \& Leisinger, T. (1988). Coculture of defined bacteria to degrade seven sulfonated aromatic compounds: efficiency, rates and phenotypic variations. $\mathrm{Appl}$ Microbiol Biotechnol 29, 605-609.

Tindall, B. J. (1990). Lipid composition of Halobacterium lacusprofundi. FEMS Microbiol Lett 66, 199-202.

Urakami, T., Araki, H., Oyanagi, H., Suzuki, K.-I. \& Komagata, K. (1992). Transfer of Pseudomonas aminovorans (den Dooren de Jong 1926) to Aminobacter gen. nov. as Aminobacter aminovorans comb. nov. and description of Aminobacter aganoensis sp. nov. and Aminobacter niigataensis sp. nov. Int $J$ Syst Bacteriol 42, 84-92.

Zürrer, D., Cook, A. \& Leisinger, T. (1987). Microbial desulfonation of substituted naphthalenesulfonic acids and benzenesulfonic acids. Appl Environ Microbiol 53, 1459-1463. 